\title{
Biochemical Impact of Fodder Galega (Galega orientalis Lam.) on Agro-ecosystems
}

\author{
Ligita Baležentienè, Albinas Kusta \\ Aleksandras Stulginskis University, Lithuania
}

crossref http://dx.doi.org/10.5755/j01.erem.58.4.678

(received in September, 2011, accepted in December, 2011)

\begin{abstract}
Multifunctional allelochemicals activities stimulate an increase in an employment spectrum of biologically active compounds in biological farming. The understanding of the allelochemical action mechanisms makes it possible to use these compounds to enhance crop production and develop a more sustainable agriculture, including weed and pest control through crop rotations, residue management and a variety of approaches in bio-control.

The aim of this research was to establish and to compare the total amount of phenolic compounds and allelopathic activity of the aqueous extracts produced of different shoot parts (leaves, stems, blossoms and seed) and roots of new crop, namely fodder galega at their different growth stages.

Biochemical impact of the aqueous extracts produced of fodder galega ground part and roots on the germination data of the test-object subjected significantly on the galega growth stage and extract concentration. The biochemical effect of all tested extracts and concentrations had the same tendency to inhibit the test-object seed germination. The extracts of the ground part were more toxic than those of roots and had a stronger suppressive effect on the test-plant germination. Phenols concentration and conventional coumarine unit (CCU) content increased evenly in dependence on total phenols concentration at all plant development stages accordingly to the extracts concentration gradient. Phenols concentration as well as their activity of ground part and roots increased from shooting to flowering stage.
\end{abstract}

Key words: ecology, allelopathy, galega, phenols.

\section{Introduction}

The phenomenon of allelopathy encompasses all types of chemical interactions among organisms in all ecosystems. Biochemical or alleochemical interactions are considered as effects of chemical compounds (allelochemicals) released from plants, including other existing types of organisms in their vicinity (Broekaert et al. 1997, Blanco 2007, Louis et al. 2007). Allelopathy is tightly coupled with competition for resources and stress caused by disease, temperature extremes, moisture deficit and herbicides. Such stresses often increase allelochemical production and accentuate their action. Allelopathic inhibition typically results from a combination of allelochemicals which interfere with several physiological processes in the receiving plant or other organisms. Allelochemicals as biological active compounds released from growing donor plants, their secretions and residue have multifaceted influences on receptor species and ecosystems in total (Alford et al. 2007, Macías et al. 2007, Weih et al. 2008). They influence soil microbial ecology, soil nutrients also physical, chemical and biological soil features. Effects

of any one of these abiotic and biotic constituents of soil and other components of ecosystems may influence growth, distribution, productivity and total survival of plant species (Inderjit, Dakshini 1999; Carlini, Grossi 2002). Allelopathy is one of many in ecosystems existing interactions such as organisms interference, microbial nutrient immobilization, mycorrhizal activity whose separating is difficult if not impossible (Anaya 1999, Wu et al. 2001). 
Involvement of eco-physiologists and microbiologists widened the scope of allelopathic research and identification, while isolation, characterization of allelopathic compounds and determining of their role importance as stress factors in interference were demonstrated as well (Inderjit 2006, Ninkovic et al. 2007). These studies have emphasized the significance of understanding the multifunctional aspects of allelopathy in structuring trophic levels, affecting predators and pests, forming symbiotic relations, mediating competitive circumstances. Allelopathic interactions include both inhibitory and stimulatory effects of allelochemicals released or incorporated in plant debris. Nowadays a great attention is paid to identification of plant physiological active compounds, their production and application as components to bio-preparations: phytoherbicides, phytopesticides, etc. (Pistelli et al. 2002, Hoagland et al. 2008).

The main allelochemicals are phenolic compounds which are common for plant cell (Ignat et al. 2011). Plant may concentrate $1-3 \%$ of phenols in fresh mass (Popa et al. 2008, Grodzinsky 1990). Plant phenolics have the potential to influence soil nutrients and implement the growth pattern (Qu, Wang 2008).

The objectives of this research were to establish and compare the total amount of phenolic compounds and allelopathic activity of the aqueous extracts produced of different shoot parts (leaves, stems, blossoms, and seed) and root of new crop fodder galega at their different growth stages.

\section{Methods}

Perennial stand of fodder galega (Galega orientalis Lam.) grown in the Training Farm of the Lithuanian University of Agriculture was used for investigation of allelopathic potential of that crop. Allelopathic impact (phenols content, total concentration and dynamics, influence on seed germination) of fodder galega was examined at the Lithuanian University of Agriculture.

The soil was characterized as sandy moraine loam humic horizon of Calcari-Epihypogleyic Luvisol $(\mathrm{LVg}-\mathrm{p}-\mathrm{w}-\mathrm{cc})$. The soil $\mathrm{pH}$ varied from 7.1 to 7.0, humus content was medium $2.3-2.5 \%$, available $\mathrm{P}_{2} \mathrm{O}_{5}$ $180 \mathrm{mg} \mathrm{kg}^{-1}$ and $\mathrm{K}_{2} \mathrm{O} 209 \mathrm{mg} \mathrm{kg}^{-1}$. The agrochemical analyses were carried out at the Agrochemical Research Centre of the Lithuanian Institute of Agriculture. Soil $\mathrm{pH}_{\mathrm{KCl}}$ was analyzed by potentiometric method, mobile $\mathrm{P}_{2} \mathrm{O}_{5}$ and $\mathrm{K}_{2} \mathrm{O}$ by acetone-lactate (A-L) analysis method, and humus percentage by Tyurin methods.

Allelopathic activity of fodder galega and its separate parts was estimated on the basis of seed germination bio-screening and recalculating to conventional coumarine units $(\mathrm{CCU})$ according to A.
Grodzinsky's method (1990). The plants of fodder galega were sampled in spring, summer and autumn for producing aqueous extracts which were used for bio-screening. The biochemical (allelopathic) characteristics of fodder galega aqueous extracts at their different growth stages: shooting $\left(2^{\text {nd }}\right.$ ten-day period of May), budding ( $3^{\text {rd }}$ ten-day period of May), flowering ( $1^{\text {st }}$ ten-day period of June), seed wax maturity ( $1^{\text {st }}$ ten-day period of July) and in autumn ( $1^{\text {st }}$ ten-day period of September) were examined. The plant samples were taken at the periods when $50 \%$ of plants in the stand had reached the same growth stage.

The $0.2,0.1,0.05$ and $0.02 \%$ concentrations of fodder galega whole shoot and root aqueous extracts were produced and examined at every growth stage. The extracts of $0.2 \%$ concentration produced of separated plant parts (leaves, stems, blossoms and roots) were estimated at a flowering stage as well as from seeds $(0.2 \%)$ at a wax maturity stage.

The total content of phenolic compounds as the essential allelopathic characteristic for plant cells was estimated according to Slinkard and Singleton (1977) photo-calorimetric method using Folin-Ciocalteau reagent (Inderjit 2006). Chlorogenic acid was used as a standard phenolic compound. $1 \mathrm{ml}$ of extract solution was mixed with $45 \mathrm{ml}$ of distilled water. One millilitre of Folin-Ciocalteu reagent was added and the content of the flask was mixed thoroughly. After $3 \mathrm{~min} 3 \mathrm{ml}$ of $\mathrm{Na}_{2} \mathrm{CO}_{3}$ was added, then the mixture was allowed to stand for $2 \mathrm{~h}$. The absorbance was measured at $760 \mathrm{~nm}$. The concentrations of phenolic compounds in the plant aqueous extracts were expressed as parts per million (ppm) equivalents to chlorogenic acid.

According to the bio-method of A. and D. Grodzinsky (1990), the seed germination screening was applied and used for recalculating of biochemical activity into conventional coumarine units (CCU). Quickly germinated rape (Brassica napus L.) cv. 'Valesca' was chosen as the receptor plant. One hundred seeds of rape were placed on filter paper in each 6-cm diameter Petri dish. Five $\mathrm{ml}$ aqueous plant extract $(0,0.2,0.1,0.05$ and $0.02 \%$ concentration) was added per Petri dish as per treatment. Treatments were replicated four times. Petri dishes were kept at $+25{ }^{\circ} \mathrm{C}$ for $16 \mathrm{~h}$. Seeds sown in distilled water served as control.

The weather conditions that influenced growth, growth and biochemical qualities of the fodder galega were adverse due to lasting droughts.

The confidence limits of the data were based on the student's theoretical criterion. The least significant difference $\left(\mathrm{LSD}_{05}\right)$ and standard deviation (SD) were calculated at the level of statistical significance $\mathrm{p}<0.05$. The results of allelopathic effects were statistically processed using the statistical package Statistica of StatSoft for Windows standards. 


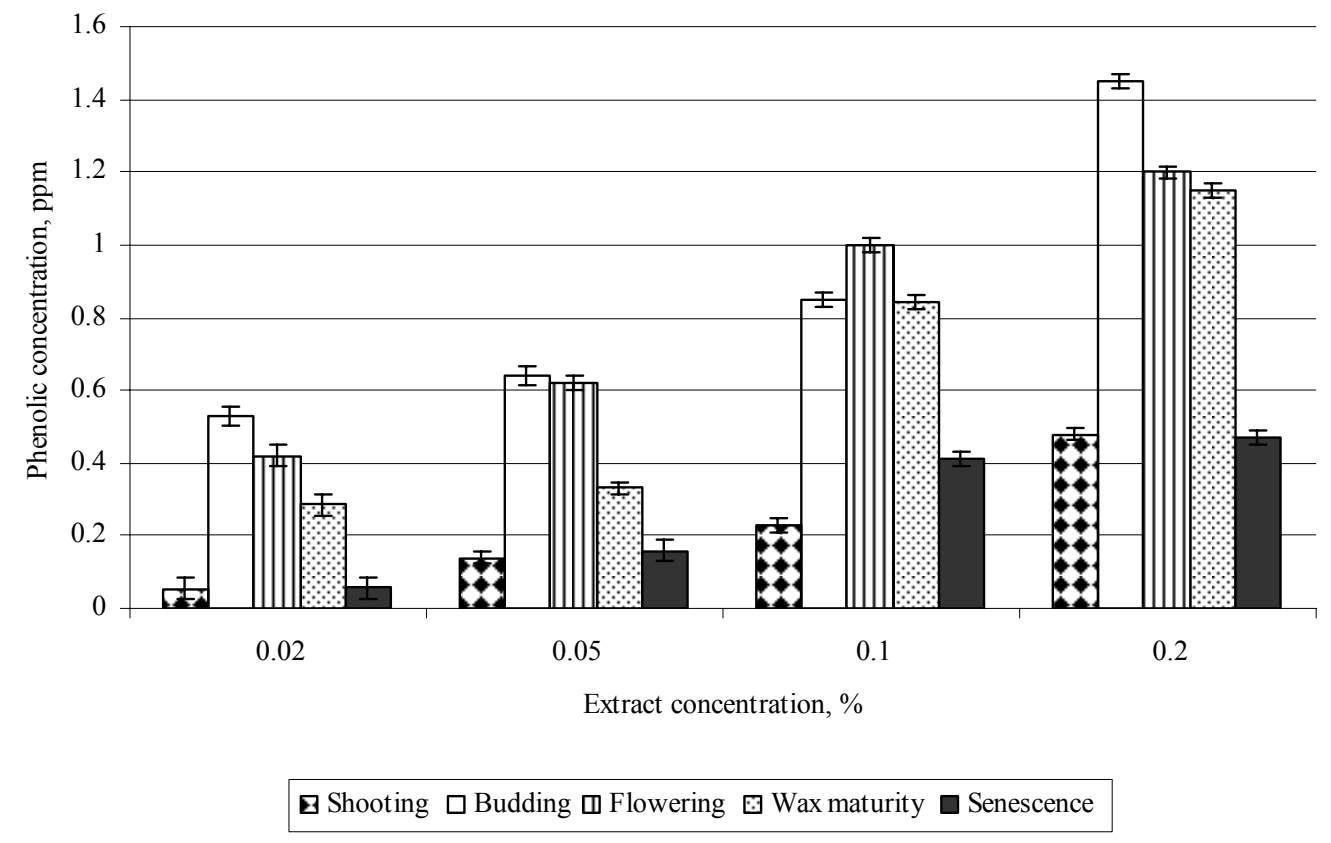

Fig. 1. Variation of phenolic compounds concentration in fodder galega shoot extracts at different growth stages $(p<$ 0.05; mean $\pm S D$ )

\section{Results and Discussion}

\subsection{Phenolic concentration during growth stages}

Phenolics concentration measurement model was chosen to estimate their content at different growth stages of galega (Ignat et al. 2011). The highest total content of phenols was determined at a budding stage which was characterized as the most intensive growth period of galega shoot of (Fig. 1).

With an exception of $0.05 \%$ concentration, all shoot extracts at a budding stage had the highest phenolics concentration (0.555-1.445 ppm), but their biological activity was less in comparison with extracts at a flowering stage. Different activity of higher concentration extracts may indicate the presence of different phenolics composition
(Baležentienè, Sėžienė 2010). As Varnaitė (1994) reported, the phenols composition fluctuated during fodder plants vegetation. More precise estimation of biochemical activity is required with identification of phenols composition in galega vegetative extracts. Biochemical activity was recorded less of shoot extracts at a flowering stage than that of a budding stage due to a decrease in phenols concentration (0.425-1.205). These extracts indicated the strongest suppressive activity on seed germination.

Many authors noted the multifaceted importance of allelopathy in soil nutrient dynamics, microbial and rhizosphere ecology of natural and agricultural soils (Dakshini 2000, Inderjit 2006, Blanco 2007). Phenolics concentration in galega root extracts ranged between $0.058-0.512 \mathrm{ppm}$ and was significantly lower in comparison with shoot (Fig. 2).

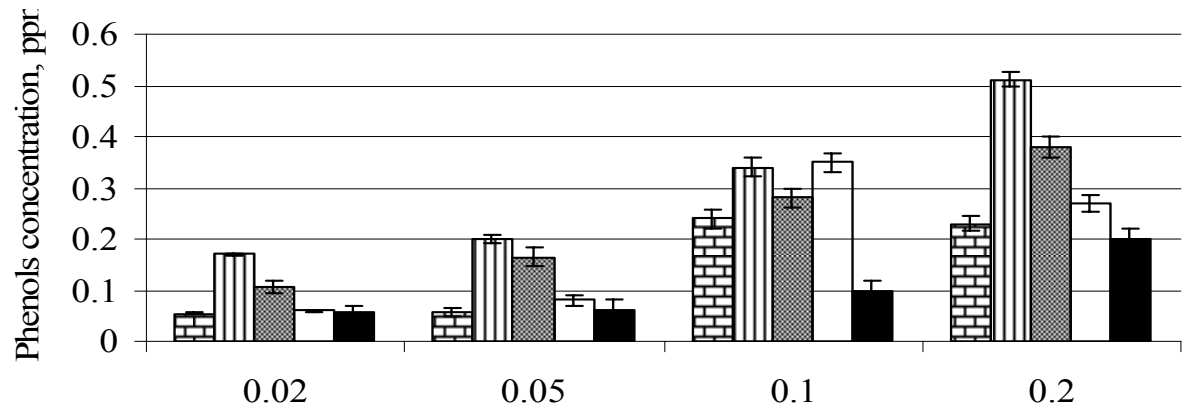

Extract concentration, \%

巴 Shooting 四Budding $\quad$ Flowering $\quad \square$ Waxmaturity

Fig. 2. Variation of phenolic compounds concentration in fodder galega root extracts at different growth stages ( $p<$ 0.05 ; mean $\pm S D$ ) 
The highest phenols concentration was determined at budding and flowering stages with the exception of $0.1 \%$ extract at a seed wax maturity stage. The least phenolics concentration was recorded at seed wax maturity $(0.06-0.27 \mathrm{ppm})$ and in autumn $(0.058-0.2 \mathrm{ppm})$. Variations of galega total phenols concentration during vegetation affirm the influence of environment and climate factors on production and release of these allelochemicals (Anaya 1999). Negligible concentrations of phenols indicate the low level toxicity of root exudates. These results suggest that galega is suitable for long-term growing in the same place without causing soil chemical exhaustion.

\subsection{Content of conventional coumarine units}

Inderjit et al. (2000), Inderjit (2006), Wu et al. (2003) and Broeckling, Vivanco (2008) have reported that phenols have a very diverse agro-ecological impact. They are the basic phytotoxins causing soil chemical degradation, inhibiting oxidation of $\mathrm{NH}_{4}^{+}$to $\mathrm{NO}_{3}^{-}$, reducing the rate of decomposition and $\mathrm{N}$ mineralization, influencing soil inorganic ions, etc. Therefore it is important to determine the phenols content in cultivated crops.

The toxicity and biochemical activity of galega aqueous extracts were expressed by conventional coumarine units (Grodzinsky 1990). In accordance with Kryževičienè, Paplauskienè (2002) and Grodzinsky (1990) reports, the total content of CCU ranged between 8.1-275 depending on the growth stage and the extract concentration. This CCU rate of galega biomass was recorded to be similar to that of other forage grasses, especially to Lolium perenne (Kryževičienè, Paplauskienè 2002). CCU index suggests that phytoinhibition and allelopathic activity of galega is not higher as that of other forage grasses in agrophytocenoses. Variation of CCU content and germination had the same tendencies in galega extracts. Shoot and root $0.2 \%$ extracts tested exhibited the highest CCU content (Table 1).

The concentration of CCU content in galega shoot increased from shooting to flowering and ranged between 35-12.5 and 275-89 at a respective stage and extract concentration. The content of CCU decreased and ranged between 241-17.2 and 30-9.4 at the latest galega growth stages: seed wax maturity and in autumn $\left(2^{\text {nd }} \mathrm{cut}\right)$, respectively.

Stronger phyto-toxicity and higher CCU content were recorded of galega shoot extracts than those of root with the exception of root extracts in autumn. Low total content of phenols in root extracts indicated extensive galega impact on soil chemical characteristics, but more detailed investigations are needed to study the composition and impact of galega phenols.

Table 1. Content of conventional coumarine units in fodder galega shoot and root

\begin{tabular}{|c|c|c|c|c|c|}
\hline $\begin{array}{l}\text { Extract concentration, } \\
\%\end{array}$ & Shooting & Budding & Flowering & Wax maturity & Senescence \\
\hline \multicolumn{6}{|c|}{ Shoot } \\
\hline Control & 8.4 & 8.4 & 8.4 & 8.4 & 8.4 \\
\hline $0.2 \%$ & 35 & 113 & 275 & 241 & 30 \\
\hline $0.1 \%$ & 28 & 106 & 241 & 27.3 & 23.9 \\
\hline $0.05 \%$ & 18.2 & 43 & 192 & 23 & 16.4 \\
\hline $0.02 \%$ & 12.5 & 19.4 & 89 & 17.2 & 9.4 \\
\hline $\mathrm{LSD}_{05}$ & 2.41 & 3.61 & 4.98 & 4.03 & 2.51 \\
\hline \multicolumn{6}{|c|}{ Root } \\
\hline Control & 8.4 & 8.4 & 8.4 & 8.4 & 8.4 \\
\hline $0.2 \%$ & 30.5 & 27.3 & 64.9 & 64.9 & 39.1 \\
\hline $0.1 \%$ & 18.9 & 21.2 & 59 & 43 & 37.5 \\
\hline $0.05 \%$ & 15.7 & 15.7 & 51 & 26.1 & 16.7 \\
\hline $0.02 \%$ & 11.5 & 11.5 & 48.9 & 8.1 & 11.5 \\
\hline $\mathrm{LSD}_{05}$ & 2.37 & 1.82 & 1.78 & 2.04 & 2.01 \\
\hline
\end{tabular}

\subsection{Phyto-inhibitory effect of shoot}

The character of biochemical impact of the aqueous extracts produced from fodder galega shoot on the germination data depended significantly on a different growth stage and extract concentration (Fig. 3).

The biochemical effect of all extracts and concentrations tested exhibited the same trend of inhibiting germination. As many authors reported (Wu et al. 2003; Chun et al. 2005; Orr et al. 2005), the extracts of the fodder galega shoot were more toxic than those of root and had a stronger suppressive effect on the receptor plant germination. $0.2 \%$ extracts showed the strongest phyto-inhibitory effect on seed germination (24\%) at a flowering stage. Allelopathic activity of shoot extracts decreased sequentially in accordance with descending 
concentration at all growth stages. Germination at $0.05-0.02 \%$ concentrations ranged from $46-64 \%$ at a flowering stage to $84-96 \%$ in autumn. The allelopathic effect on seed germination of fodder galega shoot increased with plant age from shooting to budding-flowering stages and ranged between 96$24 \%$. At the seed wax maturity the allelopathic effect stopped to decline. At this stage the strongest
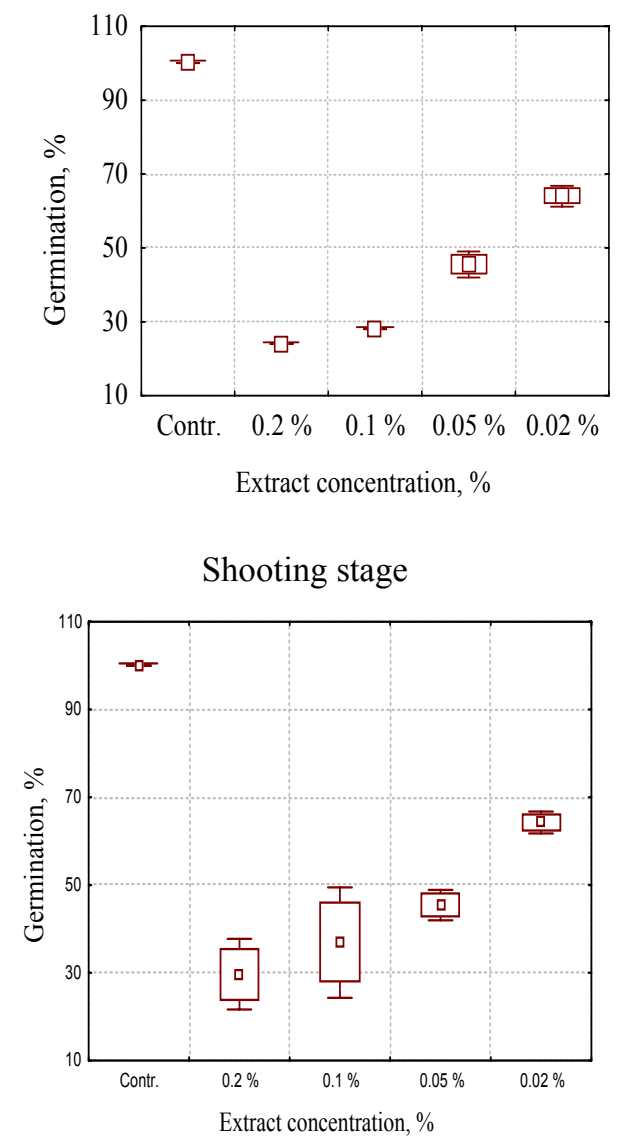

Flowering stage inhibition of seed germination $(28 \%)$ was determined at the maximal $0.2 \%$ extract concentration. The germination significantly increased from 72 to $83 \%$ with a decrease in extract concentration from 0.1 to $0.02 \%$. The minimal level of allelopathic impact was recorded at a senescence stage and seed germination ranged between $70-96 \%$ depending on the extract concentration.

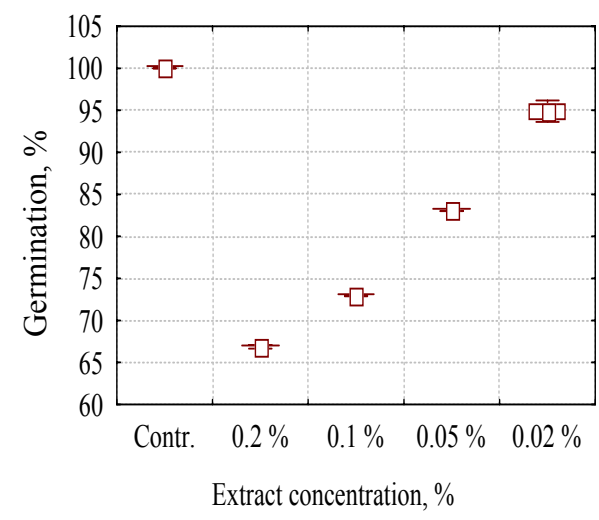

Budding stage

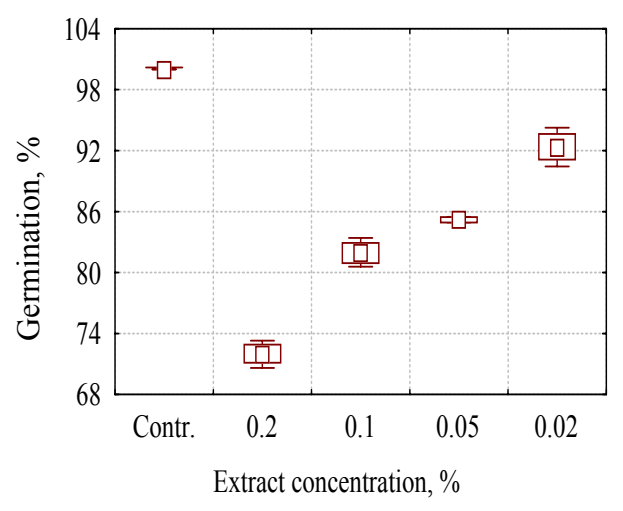

Seed wax maturity stage

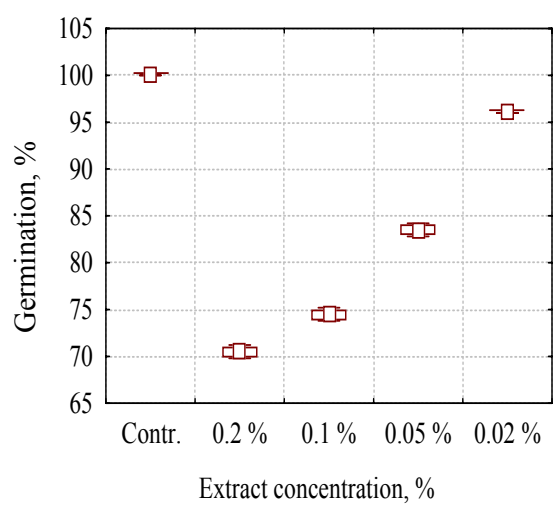

Senescence stage

Fig.3. Phyto-inhibitory impact of fodder galega shoot on germination at different stages $(p<0.05$; square - mean, rectangle - SE, whiskers - SD) 


\subsection{Phyto-inhibitory effect of root}

Root extracts of fodder galega were less inhibitory to germination than shoot extracts and showed not only the inhibitory effect (Fig. 4). Seed germination ranged between $53-101 \%$ in root

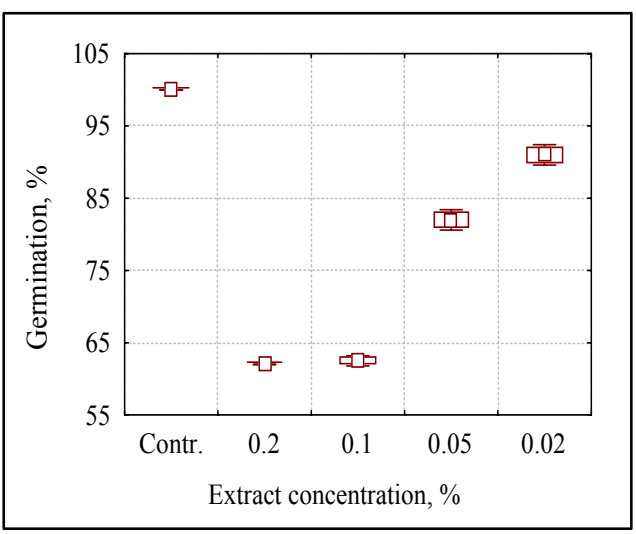

Shooting stage

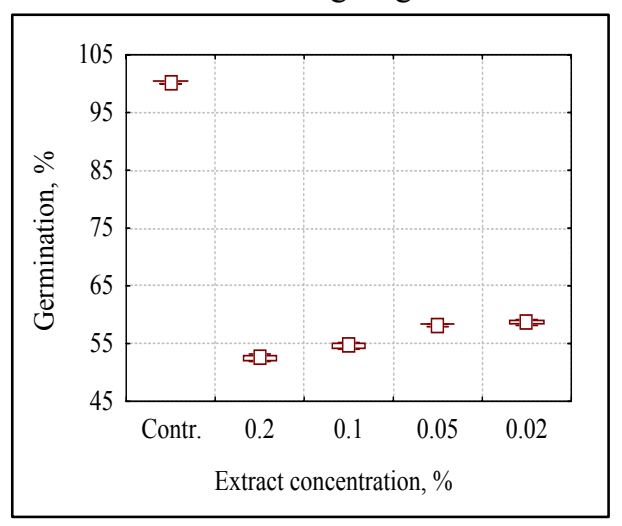

Flowering stage

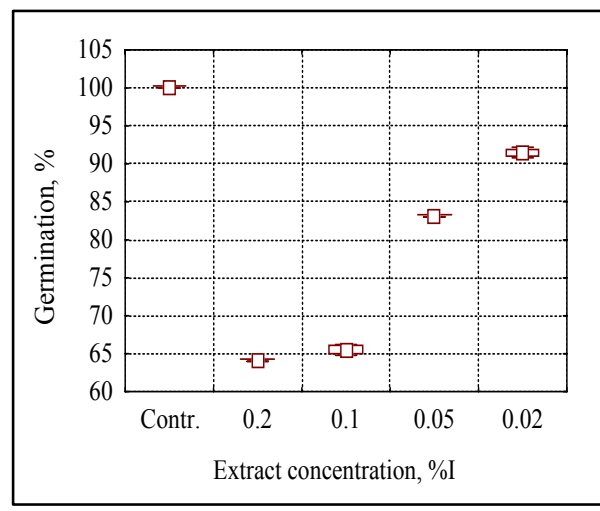

Senescence stage extracts. Only the least concentration of the root extract tested exhibited an exceptionally weak stimulatory effect $(101 \%)$ at seed wax maturity in contradistinction to the inhibitory effect of other root and shoot treatments.

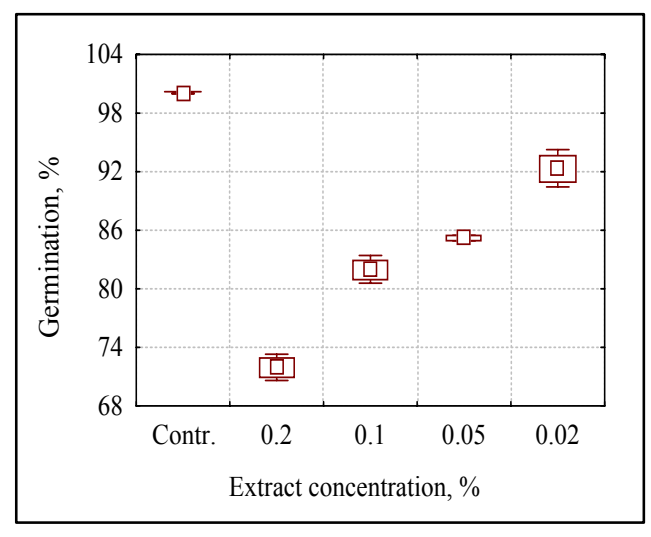

Budding stage

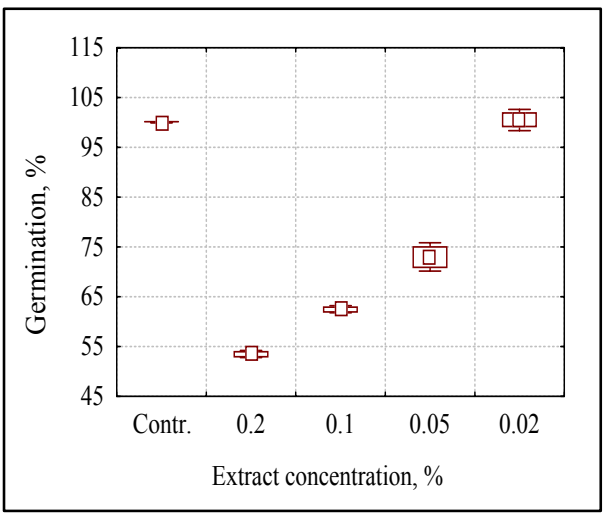

Seed wax maturity stage

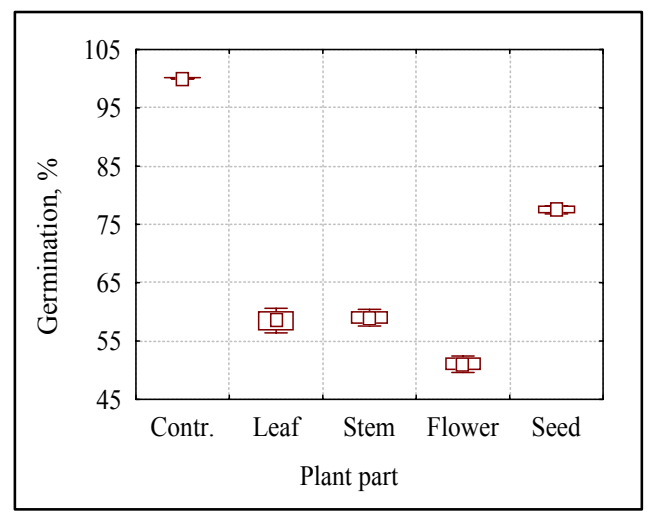

Flowering stage

Fig.4. Phyto-inhibitory effect of root and different fodder galega parts on germination at different stages $(p<0.05$; square - mean, rectangle - SE; whiskers - SD)

Alelopathic effect of root extracts had no such evident impact on seed germination during plant vegetation as the shoot ones. The strongest inhibitory effect of extracts on germination was recorded only at flowering and seed wax maturity stages. A noteworthy fact is that during flowering the seed germination fluctuated within a rather narrow range
53-59\%. The tested extracts were less active in spring and autumn. Under the effect of these extracts the germination ranged between 71-92 and 64-92\%, respectively.

The descending concentration of root extracts showed the tendency to reduce the inhibitory effect on seed germination. The extracts of the greatest 
concentration $(0.2 \%)$ in all stages were more toxic and showed the strongest suppressive effect on the germination of receptor plant.

\subsection{Phyto-inhibitory effect of shoot parts}

The strongest suppressive effect of extracts was determined at a flowering stage. $0.05 \%$ aqueous extracts of shoot vegetative (leaves and stem) and generative (florets and seed) parts were produced and processed at a flowering stage, also of seed at a wax maturity stage. All of them suppressed seed germination (Fig. 4).

While ground and macerated materials are thought to be less ecologically meaningful (Inderjit, Callaway 2003), the fodder galega inflorescence extract indicated the highest toxicity. The seed germination was only $55 \%$ under the effect of inflorescence extract. The inhibitory effect of the stem and root extracts decreased, under which the germination amounted to 57 and $58 \%$ or was by 43 and $42 \%$ lower compared to the control. The germination was determined by $39 \%$ less in leaf extract than that in control treatment.

Among the tested extracts the seed extract had the minimal toxic and suppressive effect on germination. Therefore germination was significantly the highest $(73 \%)$ in this extract than in the other treatments.

\section{Conclusions}

Our results suggest that allelochemicals of the aerial part of fodder galega (Galega orientalis Lam.) are more phytotoxic than those of its roots due to the higher phenols content. Nevertheless, participation of other bioactive compounds could not be excluded. The maximal allelopathic potential of aerial plant part was detected at a flowering stage and phenolic compounds could be involved. The extracts with different inhibitory impact on germination and CCU rates depended on a galega growth stage, plant parts and an extract concentration gradient. Galega extracts of the least concentrations $(0.05 \%$ and $0.02 \%)$ indicated the minimal biochemical activity at a shooting stage and in autumn compared to those of the highest concentrations $(0.1$ and $0.2 \%)$ at a flowering stage. More research is needed to determine the real effect of fodder grass allelochemicals on representative receptor plants I natural conditions

\section{References}

ALFORD, É.R., PERRY, L.G., QIN, B., VIVANCO, J.M., PASCHKE, M.W. A putative allelopathic agent of Russian knapweed occurs in invaded soils, Soil Biology, Biochemistry, 2007, Vol. 39, No.7, p. 1812-1815. http://dx.doi.org/10.1016/j.soilbio.2007.01.020
ANAYA, A. L. Allelopathy as a tool in the management of biotic resources in agroecosystems, Critical Reviews in Plant Sciences, 1999, Vol. 18, No.6, pp. 697739. http://dx.doi.org/10.1080/07352689991309450

BALEŽENTIENĖ, L., SĖŽIENĖ, V. Biochemical impact of dominants' extracts of Scots pinewood cuttings on germination, Polish Journal of Environmental Studies, 2010, Vol. 19, No.1, pp.35-42.

BLANCO, J. A. The representation of allelopathy in ecosystem-level forest models, Ecological Modeling, 2007, Vol. 209, No. 2-4, pp. 65-77. http://dx.doi.org/10.1016/j.ecolmodel.2007.06.014

BROECKLING, C.D., VIVANCO, J.M. A selective, sensitive and rapid in-field assay for soil catechin, an allelochemical of Centaurea maculosa, Soil Biology and Biochemistry, 2008, Vol. 40, No. 5, pp. 1189-1196. http://dx.doi.org/10.1016/j.soilbio.2007.12.013

BROEKAERT, W.F., CAMMUE, B.P.A., DEBOLLE, M.F.C., THEVISSEN, K., DESAMBLANX, G.W., OSBORN, R.W. Antimicrobial peptides from plants, Critical Reviews in Plant Sciences, 1997, Vol. 16, pp. 297323.

CARLINI, C.R., GROSSI, de SA F. Plant toxic proteins with insecticidal properties: a review on their potentialities as bioinsecticides, Toxicon, 2002, Vol. 40, pp. $1515-1539$.

0101(02)00240-4

CHUN, S. U., JANG, H. G., KIM, D. K., KIM, Y.M.; BOO, H.O, KIM, YJ. Allelopathic potential in lettuce (Lactuca sativa L.) plants, Scientia Horticulturae, 2005, Vol. 106, No. 3, pp. 309-317. http://dx.doi.org/10.1016/j.scienta.2005.04.005

IGNAT, I., VOLF, I., POPA, V.I. A critical review of methods for characterization of polyphenolic compounds in fruits and vegetables, Food Chemistry, 2011, Vol. 126, pp. $1821-1835$.

http://dx.doi.org/10.1016/j.foodchem.2010.12.026

INDERJIT, CALLAWAY, R.M. Experimental design for the study of allelopathy, Plant Soil, 2003, Vol. 256, pp. 1-11. http://dx.doi.org/10.1023/A:1026242418333

INDERJIT, DAKSHINI, K.M.M. Principles and Practices in Plant Ecology: Allelochemical Interactions. CRC Press, 1999, pp. 35-40.

INDERJIT. Experimental complexities in evaluating the allelopathic activities in laboratory bioassays: a case study, Soil Biology and Biochemistry, 2006, Vol. 38, No. 2, pp. 262.

GRODZINSKY, A.M. Allelopathy and Productivity of Plants. Naukova Dumka: Kijev, 1990. p. 160.

HOAGLAND, L., CARPENTER-BOGGS,L., REGANOLD, J.P., MAZZOLA, M. Role of native soil biology in Brassicaceous seed meal-induced weed suppression, Soil Biology and Biochemistry, 2008, Vol. 40, pp.

http://dx.doi.org/10.1016/j.soilbio.2008.02.003
1689-1697. 
KRYŽEVIČIENĖ， A., PAPLAUSKIENĖ， V. Allelopathic activity of perennial grasses at different development stages, Žemdirbystè-Agriculture, 2002, Vol. 4, No. 80, pp. 179-192

LOUIS, S., DELOBEL, B., GRESSENT, F., Duporta, G., DIOLA, O., RAHIOUIA, I., CHARLESA, H., RAHBÉ $Y$. Broad screening of the legume family for variability in seed insecticidal activities and for the occurrence of the Alb-like knotting peptide entomotoxins, Phytochemistry, 2007, Vol. 68, No. 4, pp. 521-535. http://dx.doi.org/10.1016/j.phytochem.2006.11.032

MACÍAS, F.A., GALINDO, J., GALINDO, J.C.G. Evolution and current status of ecological phytochemistry, Phytochemistry, 2007, Vol. 68, No. 22-24, pp. 2917-2936. http://dx.doi.org/10.1016/j.phytochem.2007.10.010

NINKOVIC, V., GLINWOOD, R., PETTERSON, J. Communication between undamaged plants by volatiles: the role of allelobiosis. Communication in Plants. Verlag, Berlin, 2007, pp. 421-434.

ORR, S.P., RUDGERS, J.A., CLAY, K. Invasive plants can inhibit native tree seedlings: testing potential allelopathic mechanisms, Plant Ecology, 2005, Vol. 181, pp. 153-165. http://dx.doi.org/10.1007/s11258-005-5698-6

PISTELLI, L., BERTOLI, A., LEPORI, E., MORELLI, I., PANIZZI L. Antimicrobial and antifungal activity of crude extracts and isolated saponins from Astragalus verrucosus, Fitoterapia, 2002, Vol. 73, pp. 336339. http://dx.doi.org/10.1016/S0367-326X(02)00087-4

POPA, V.I., DUMITRU, M., VOLF, I., ANGHEL, N. Lignin and polyphenols as allelochemicals. Industrial Crops and Products, 2008, Vol. 27, No. 2, pp. 144-149. http://dx.doi.org/10.1016/j.indcrop.2007.07.019

SLINKARD, K., SINGLETON, V.L. Total phenol analyses: automation and comparison with manual methods, Am. J. Enol. Viticult. 1977, Vol. 28, 49-55.

VARNAITĖ, R. Atskirų genčių pašarinių augalų fenoliniai junginiai ir jų mikrobiologinè degradacija: habilitacinio darbo santrauka. BI,Vilnius, 1994. p. 72.

QU, X. H., WANG, J. G. Effect of amendments with different phenolic acids on soil microbial biomass, activity and community diversity, Applied Soil Ecology, 2008, Vol. 39, No. $2, \quad$ pp. $172-179$. http://dx.doi.org/10.1016/j.apsoil.2007.12.007

WEIH, M., DIDON, U.M.E., RÖNNBERGWÄSTLJUNG, A.C., BJÖRKMAN, C. Integrated agricultural research and crop breeding: Allelopathic weed control in cereals and long-term productivity in perennial biomass crops, Agricultural Systems, 2008, Vol. 97, No.3, pp. 99-107. http://dx.doi.org/10.1016/j.agsy.2008.02.009

WEIR, T. L., BAIS, H.P., VIVANCO, J.M. Intraspecific and interspecific interactions mediated by a phytotoxin, catechin, secreted by the roots of Centaurea maculosa (spotted knapweed), Journal of Chemical Ecology, 2003, Vol. 29, pp. 2397-2412. http://dx.doi.org/10.1023/A:1026313031091

WILLIS, R.J. The historical basis of the concept of Allelopathy, Journal History of Biology, 1985, Vol. 18, pp. 71. http://dx.doi.org/10.1007/BF00127958

WU, H., PRATLEY, J., HAIG, T. Phytotoxic effects of wheat extracts on a herbicide-resistant biotype of annual ryegrass (Lolium rigidum), Journal of Agricultural and Food Chemistry, 2003, Vol. 51, No. 6, pp. 4610-4616. http://dx.doi.org/10.1021/jf026010w

WU, H., PRATLEY, J., LEMERLE, D., HAIG, T., AN, M. Screening methods for the evaluation of crop allelopathic potential, Botanical Review, 2001, Vol. 67, pp. 403-415. http://dx.doi.org/10.1007/BF02858100

Dr. Ligita Baležentienė, Assoc. Professor, Institute of Environment, Aleksandras Stulginskis University (ASU).

Main research areas: plant ecology, biodiversity, bioindication, soil bioactivity, climate change, environment engineering and landscape management.

Address: Studentų 11, Akademija,

$\begin{array}{ll} & \text { 53361, Kaunas } \\ \text { Tel.: } & +37037752202\end{array}$

E-mail: $\quad$ ligita.balezentiene@1zuu.lt

Dr. Sc. Albinas Kusta, Academician, Prof., Deptartment of Hydraulic Engineering, Aleksandras Stulginskis University (ASU). Director of Slènis Nemunas. Membership: a full member of the Lithuanian Academy of Sciences. Rector of LUA (1994-2004).

Main research areas: environment engineering and landscape management

Address: Studentų 11, Akademija,

Tel. 53361, Kaunas distr. Lithuania

Tel.: $\quad+37037752303$

E-mail: $\quad$ albinas.kusta@1zuu.lt 


\title{
Rytinio ožiarūčio (Galega orientalis Lam.) biocheminis poveikis agroekosistemoms
}

\author{
Ligita Baležentienè, Albinas Kusta
}

Aleksandro Stulginskio universitetas, Lietuva

(gauta 2011 m. rugsèjo mèn.; atiduota spaudai 2011 m. gruodžio mèn.)

Daugiafunkcinis alelochemikalu aktyvumas skatina plèsti biologiškai aktyvių junginių panaudojimo galimybes biologiniame ūkininkavime. Alelochemikalų veikimo mechanizmo supratimas leidžia mums naudoti šiuos junginius skatina gerinti augalų produktyvumą ir plètoti tvarų žemės ūki, ịskaitant piktžolių ir kenkẻjų kontrolès per sẻjomainą, likučių valdymą ir biologinès kontrolès metodu ịvairovę.

Pagrindinis šio tyrimo tikslas buvo nustatyti ir palyginti bendrą fenolinių junginių kiekị ir alelopatini aktyvumą vandeniniuose ekstraktuose, pagamintuose iš rytinio ožiarūčio įvairių ūglio dalių (lapų, stiebų, žiedų ir sẻklų) ir šaknų skirtingose augimo stadijose.

Biocheminis poveikis vandeninių ekstraktų, pagamintų iš pašarų ožiarūčių antžeminès dalies ir šaknų daigumo rezultatai patikimai priklausè nuo augimo tarpsnio ir ekstrakto koncentracijos. Visų tirtų ekstraktu ir koncentracijų biocheminis poveikis rodè tą pačią tendenciją slopinti bandymo objekto sèklų daigumą. Antžeminès dalies ekstraktai buvo labiau toksiški ir stipriau slopino daigumą nei šaknų ekstraktai. Fenolių koncentracija ir sutartinių kumarino vienetų (CCU) kiekis didèjo tolygiai priklausomai nuo bendros fenolių koncentracijos visais augalų vystymosi tarpsniais pagal ekstraktų koncentracijos gradientą. Fenolių koncentracija, taip pat jų aktyvumas antžeminèje dalyje ir šaknyse didèjo nuo krūmijimosi iki žydẻjimo tarpsnio. 